\title{
Intelligence and Controversial British Interrogation Techniques: the Northern Ireland Case, 1971-2*
}

\author{
Samantha Newbery \\ Department of History, Trinity College Dublin
}

\begin{abstract}
This paper focuses on the controversial British interrogation techniques known as the 'five techniques', which were used as aids to interrogation in Northern Ireland in the autumn of 1971. Its central argument is that despite the widespread backlash against the use of the 'five techniques' in Northern Ireland, the Ministry of Defence (MoD) in Britain continued to support their use because of their benefits to intelligencegathering. By examining the written histories of the 'five techniques' commissioned by the MoD and the course of MoD-led debates on the purposes of the techniques, we can gain an insight into official attitudes towards past and future uses of the techniques. Bolstered by evidence on the quantity and quality of the intelligence these techniques produced in the Northern Ireland case, this study contributes to debates on the relationship between intelligence-gathering and interrogation methods that can be described as ill-treatment or torture.
\end{abstract}

\section{INTRODUCTION}

In the autumn of 1971 fourteen men held under internment in Northern Ireland were interrogated by the British security forces using techniques that received condemnation at home and abroad. The use of these 'five techniques', as they were known, and the inadequacies perceived in the British response to their use and to other alleged incidents of ill-treatment, played a significant role in the Republic of Ireland's decision to prosecute the UK for breaches of the European Convention on Human Rights (ECHR) in November 1971. Oral and written submissions made to the European Commission of Human Rights in Strasbourg by the UK and Ireland contained intense debates on the facts surrounding numerous, and geographically and temporally widespread, allegations of ill-treatment associated with the use of the 'five techniques', and on whether these constituted a breach of the prohibition of torture and 'inhuman or degrading treatment or punishment' enshrined in article 3 of the ECHR. ${ }^{1}$ Although the

*The author would like to thank the article's anonymous reviewers for their comments.

${ }^{1}$ Council of Europe, 'Convention for the protection of human rights and fundamental freedoms', article 3. The complete text of the convention is available at http://conventions.coe.int/treaty/en/Treaties/ Html/005.htm (7 July 2009).

Author's e-mail: newberys@tcd.ie

Irish Studies in International Affairs, Vol. 20 (2009), 103-119.

doi: 10.3318/ISIA.2009.20.103 
UK admitted it had used the 'five techniques' in Northern Ireland, the most damaging of Ireland's allegations, and the one that had the greatest consequences, was that these methods amounted to torture. In its report of January 1976 the Commission of Human Rights agreed that these methods did amount to torture when used in combination. ${ }^{2}$ However, the judges of the European Court of Human Rights disagreed, and in their 1978 report ruled that the techniques 'did not occasion suffering of the particular intensity and cruelty implied by the word torture'; they instead classified them as an act of inhuman and degrading treatment. ${ }^{3}$ This decision, as Philippe Sands has found, was used by the administration of President George W. Bush to support its argument that virtually the same techniques employed in the US government's detention centre in Guantanamo Bay also fell short of torture. ${ }^{4}$

The use of controversial interrogation methods since the terrorist attacks of September 2001 has stimulated debates on the ethics and definition of torture. This article contributes to these debates by focusing on the official justifications given in the early 1970s for the use of the 'five techniques'. The contemporary relevance of this study was increased by the recent revelation that the same techniques were used by members of the British army against ten civilians in Iraq in September 2003. Their use on that occasion has resulted in the commissioning of the Baha Mousa Public Inquiry, named after the civilian who died as a result of injuries sustained whilst being subjected to the 'five techniques'. ${ }^{5}$ By investigating how these techniques came to be used in Iraq, this public inquiry will contribute to the continuing debates on interrogation techniques.

The twelve men subjected to the 'five techniques' at the special interrogation centre in Ballykelly, near Limavady, Co. Derry, in August 1971 — and two other men who were put through the same process in October-were hooded, made to stand against a wall for prolonged periods of time, subjected to continuous white noise, permitted little sleep and fed on bread and water. ${ }^{6}$ These techniques provoked such strong protest not only because of the severity of treatment they entailed, but because they were part of policy and were taught to the Royal Ulster Constabulary (RUC) in the Spring of 1971 by the Joint Services Interrogation Wing (JSIW), Britain's 'only official school for interrogation training' ${ }^{7}$

While the use of these techniques in Northern Ireland produced numerous effects, from changes in the minority's attitudes towards the security forces to the boost given to IRA recruitment, this paper concentrates on the intelligence dimension. In particular, we examine the role played by the desire to produce tactical intelligence quickly in debates led by the Ministry of Defence (MoD) on the future of the

2Ireland's applications to the commission alleged that other ill-treatment also breached article 3; that the deaths of seven named men caused by the security forces in Northern Ireland were breaches of article 2 (the right to life); that internment without trial breached articles 5 and 6 (the right to liberty and security and the right to a fair trial); and that the exercise of internment had been carried out on the grounds of the alleged political opinion of the detainees and was therefore in breach of article 14 (the prohibition of discrimination). See King's Inns Library, Dublin, Declan Costello's papers, Report of the European Commission of Human Rights, Ireland vs UK, adopted on 25 January 1976.

${ }^{3}$ European Court of Human Rights, 'Case of Ireland v the United Kingdom', Judgment of the European Court of Human Rights, 18 January 1978, paragraph 34.

${ }^{4}$ Philippe Sands, Torture team: deception, cruelty and the compromise of law (London, 2008), 59, $89,215$.

${ }^{5}$ This revelation was made in the report published by the British Army, An investigation into cases of deliberate abuse and unlawful killing in Iraq in 2003 and 2004 (Aitken Report), 25 January 2008. The text of this report is available at: http://www.mod.uk/NR/rdonlyres/7AC894D3-1430-4AD1-911F8210C3342CC5/0/aitken_rep.pdf (7 July 2009).

${ }^{6}$ There is still some controversy over the location of the special interrogation centre, but records released into the National Archives, Kew, confirm it was Ballykelly airfield.

${ }^{7}$ The National Archives, Ministry of Defence (hereafter cited as TNA DEFE), 23/108, 'Northern Ireland-Interrogation in depth', unsigned and undated, covering letter by Sir Arthur Hockaday, Assistant under-secretary (General staff) (AUS(GS)), 13 October 1971. 
techniques. In doing this we shall see how the critical examination of these techniques resulting from the publicity surrounding their use in Northern Ireland provoked the MoD into revealing its support for the techniques, and how strongly this support was based on intelligence concerns. It must be acknowledged that although this research identifies the strength and motivations for the MoD's support for these techniques, this agenda may also have influenced the ministry's selection of evidence and construction of arguments in other unquantifiable ways. The success of interrogation is defined in this paper by the volume and quality of intelligence it produces and how quickly this intelligence is collected. Importantly, however, where possible within the scope of this article, its success is also assessed with reference to the wider impact of interrogation and the techniques used.

The first part of this paper charts how the British developed this set of five interrogation techniques in response to the demand for intelligence, in circumstances in which interrogation can be the principal source of timely intelligence. This history of the 'five techniques' begins in Kenya in 1953-4, during the first of twelve internal security operations ${ }^{8}$ throughout which the techniques developed into an effective set of what can most accurately be described as 'aids to interrogation'. The history of the 'five techniques' and the intelligence produced by interrogation during these twelve internal security operations is accessible through documents created for the Parker Inquiry, which was commissioned in November 1971 to examine 'whether, and if so in what respects, the procedures currently authorised for interrogation of persons suspected of terrorism and for their custody while subject to interrogation require amendment'. ${ }^{9}$ The Parker Inquiry formed a major part of the British government's official response to negative reactions to the use of the 'five techniques' in Northern Ireland; it was established following criticisms of the composition, remit and report of the Compton Inquiry, whose task had been to investigate the truthfulness of allegations of ill-treatment made by those arrested during the initial internment sweep of 9 August 1971. By illuminating MoD and Army Intelligence Corps attitudes towards the 'five techniques', these historical narratives help to explain how these methods came to be used in Northern Ireland.

The second part of the paper examines internal MoD debates on how to present the 'five techniques' - especially hooding, wall-standing and white noise- to the Parker Inquiry committee, and further demonstrates the strength of the MoD's continuing support for these techniques. The ministry's discussions, which also involved the Intelligence co-ordinator, reveal details of the effects of the techniques upon their subjects and thereby provide stimulating material for the current debates on the relationship between torture, or ill-treatment, and intelligence. In the final part of the paper, we turn to accounts of the intelligence gained from interrogation using the 'five techniques' in Northern Ireland, also produced by the MoD for the Parker Inquiry. This additional effort to persuade the inquiry that the benefits of the 'five techniques' for intelligence rendered them vital tools for future interrogation operations reinforces the picture of the MoD's attitudes towards these controversial methods.

\section{HISTORY OF THE 'FIVE TECHNIQUES', 1953-71}

The link between intelligence and the official histories of the 'five techniques' is hinted at in the two most detailed histories, which were written by Inspector of the

\footnotetext{
${ }^{8}$ Internal security operations can be defined as low-intensity operations, often involving counterterrorism or counter-insurgency.

${ }^{9}$ Her Majesty's Stationery Office (HMSO), Report of the Committee of Privy Counsellors appointed to consider authorised procedures for the interrogation of persons suspected of terrorism (Parker Report), Cmnd. 4901, March 1972, Terms of reference.
} 
Intelligence Corps Brigadier Bremner. ${ }^{10}$ These historical narratives, commissioned by the Ministry of Defence for presentation to the Parker Inquiry committee, are based on classified documents and official records, supplemented where possible by 'the personal recollection of officers who were involved in interrogation operations'. ${ }^{11}$ This evidence was incomplete, however, as some material remained 'the property of indigenous Police Special Branches' 12 to whom, 'for varying reasons, we [the Headquarters Intelligence Centre] no longer have access' ${ }^{13}$ The histories cover all interrogation operations that involved some or all of the 'five techniques', charting their development and detailing the intelligence obtained during these operations, in order to persuade the Parker Inquiry that these techniques and intelligence-collection go hand in hand. ${ }^{14}$ It is important to note at this point that the authors could not discover the precise dates between which the 'five techniques' were used in each case, because they too were contained in the records which the British could no longer consult. Sir James Dunnett, who as the MoD's permanent undersecretary was its civil service head, wrote that as a result, "we are...driven back to the dates between which these overseas emergencies occurred' and this 'is not quite as simple a question as might at first appear'.15

There is scholarly consensus not only on the importance of intelligence collection for success in counter-insurgency, ${ }^{16}$ but also on the assertion that interrogation 'may often be the main source of intelligence' 17 and that this intelligence must be disclosed 'as soon as possible (i.e., within hours or days) to [be of] help [to] counterinsurgency operations'. ${ }^{18}$ We shall see that Brigadier Bremner made efforts to communicate these principles and the value of using the 'five techniques' in internal security operations in his account of intelligence gained through interrogations that involved the "five techniques'. By producing documents that aimed to persuade the Parker Inquiry committee of the indispensability of the 'five techniques', the MoD also gave future researchers an insight into the mindsets that influenced the decision to transfer those techniques to Northern Ireland.

Although accounts of the emergence and development of each of the five interrogation methods in question are incomplete, Bremner was able to find that some

${ }^{10}$ TNA DEFE 23/109, Brigadier R.M. Bremner, inspector of the Intelligence Corps and commandant, 'Interrogation in international security situations since 1945' and 'Intelligence gained from interrogation operations since 1960', 18 November 1971. The other summaries are: TNA DEFE 23/109, 'Background note', unsigned [Ministry of Defence (MoD)], undated [November 1971?]; TNA DEFE 23/111, 'The evolution of handling techniques in the interrogation environment', Headquarters Intelligence Centre, 8 December 1971.

${ }^{11}$ TNA DEFE 23/109, Bremner, 'Intelligence gained from interrogation operations since 1960', 18 November 1971.

12TNA DEFE 23/109, Bremner, 'Interrogation in international security situations since 1945', 18 November 1971.

${ }^{13}$ TNA DEFE 23/111, 'The evolution of handling techniques in the interrogation environment', Headquarters Intelligence Centre, 8 December 1971.

${ }^{14}$ The complete list of operations is: Kenya, 1953-4; Cyprus, 1956-60; Malaya, 1956-60; British Cameroons, 1960-1; Swaziland, 1963; Brunei, 1963; Aden, 1964; British Guiana, 1964; Aden, 1964 7; Indonesian Confrontation, 1965-6; Oman, 1970-1; and 'Operations', 1970-1. Amongst these are seven of the nine principal low-intensity conflicts engaged in by British forces since World War II listed by David Charters. Palestine and Northern Ireland are the two missing operations. See Charters, 'From Palestine to Northern Ireland: British adaptation to low-intensity operations', in David A. Charters and Maurice Tugwell (eds), Armies in low-intensity conflict: a comparative analysis (London, 1989), 169249: 171,235

${ }^{15}$ TNA, Prime Minister's Office (hereafter cited as TNA PREM) 15/485, Sir James Dunnett, permanent under-secretary of state for defence (PUS), to Burke Trend, Cabinet secretary, 15 November 1971. 193.

${ }^{16}$ For example: Thomas R. Mockaitis, British counterinsurgency, 1919-1960 (Houndmills, 1990),

${ }^{17}$ Julian Paget, Counter-insurgency campaigning (London, 1967), 163.

${ }^{18}$ Panagiotis Dimitrakis, 'British intelligence and the Cyprus insurgency, 1955-1959', International Journal of Intelligence and Counter-Intelligence 21 (2) (2008), 375-94: 390. 
or all of the 'five techniques' were first used in 1953-4 in the Kenyan Emergency. ${ }^{19}$ He further reported that interrogation using some or all of these techniques was also used as a source of intelligence during the latter years of the 1948-60 Malayan Emergency. It is perhaps worthy of note here that the Malayan case is widely regarded as an example of counter-insurgency worth following, the lessons from which included the importance of intelligence as the key to success in counterinsurgency and of effective intelligence organisation. ${ }^{20}$

In the British Cameroons, a territory now divided between Nigeria and Cameroon, the 'five techniques' were used in 1960 and 1961 during interrogation of subversives from the neighbouring Cameroon Republic, who were using the territory as a base. On that occasion, 'of 20 high grade subjects 15 co-operated fully'. This was attributed to the use of the 'five techniques', which, as is argued in this article, the MoD was keen to make clear to the Parker Inquiry were successful aids to interrogation. ${ }^{21}$ The information obtained during the operation in the British Cameroons:

included full details of rebel training camps in Morocco and other north-west African countries-even to course syllabi. The heavy involvement of Communist China in African affairs was confirmed for the first time. ${ }^{22}$

The techniques continued to yield intelligence of a similar type and quality in subsequent internal security operations. They were also successful in two "negative operations', in the first of which interrogation ascertained that labour problems in Swaziland in 1963 were not created by a subversive organisation as had been suspected. In the second, which took place in Aden, now part of the Yemen, in January-February 1964, the information produced by the interrogation of eleven suspects arrested after a hand grenade was thrown at a party of senior officials at Aden airport supported their innocence. ${ }^{23}$

A large-scale interrogation operation involving initially some 2,000 prisoners took place in Brunei in 1963, for which three interrogation centres were established in total, with one dedicated to high-grade suspects. ${ }^{24}$ The intelligence collected in this operation was both military and political:

The TNKU [North Kalimantan National Army] Order of Battle was produced in detail...The support of the insurrection by Indonesia was confirmed and the future plans of the revolutionary leader (AZAHARI) were exposed. ${ }^{25}$

Hooding and white noise were first introduced during the Brunei operation. It was also in Brunei that, 'as far as can be ascertained, all 5 techniques were first used together'. ${ }^{26}$

The 'five techniques' should not, however, be taken as the only interrogation techniques to have an impact upon the success of interrogation. Although other 1971.

${ }^{19}$ TNA DEFE 23/109, Bremner, 'Interrogation in international security situations', 18 November

${ }^{20}$ Charters, 'From Palestine to Northern Ireland', 218-19.

${ }^{21}$ TNA DEFE 23/109, Bremner, 'Intelligence gained from interrogation operations', 18 November 1971. 1971.

22TNA DEFE 23/109, Bremner, 'Intelligence gained from interrogation operations', 18 November

${ }^{23}$ TNA DEFE 23/109, Bremner, 'Interrogation in international security situations' and 'Intelligence gained from interrogation operations since 1960’, 18 November 1971.

${ }^{24}$ TNA DEFE 23/109, Bremner, 'Interrogation in international security situations', 18 November 1971.

${ }^{25}$ TNA DEFE 23/109, Bremner, 'Intelligence gained from interrogation operations', 18 November 1971.

${ }^{26}$ TNA DEFE 23/109, 'Meeting with Mr Healey', C.A. Whitmore, secretary, Headquarters Organisation Committee, 24 November 1971. 
developments are absent from the historical narratives of the 'five techniques', and indeed from the debates examined in the rest of this paper, there are many more factors that influence the success of interrogation. The term 'interrogation techniques' is ordinarily used to refer not just to methods of questioning, but to every aspect of a prisoner's experience between arrest and release, all of which have an impact upon his/her will to cooperate. There is considerable overlap between the other commonly used terms of 'prisoner handling' and the 'interrogation environment'. Between them these broad terms describe everything the detainee experiences, from the execution of his/her arrest and transport to the interrogation centre, to the environment and treatment received at the interrogation centre itself. In addition to what happens in the interrogation room, the factors that make an impact upon a detainee at the interrogation centre include: the availability of adequate exercise, toilet and washing facilities; sufficient lighting and heating or ventilation; the quality and quantity of guards, administrators and interrogators; the quality of information on detainees made available to staff on their arrival at the centre; and 'speedy communication links with Special Branch Headquarters, or the organisation directing the interrogation' ${ }^{27}$

Experience of beatings in custody also affects prisoners' attitudes towards cooperation with their interrogators. Whereas it is known that some, at least, of the fourteen men interrogated using the 'five techniques' in Northern Ireland were beaten, ${ }^{28}$ nothing specific is known about how this affected these individuals' attitudes towards interrogation. As became clear in the proceedings initiated by Ireland before the European Commission of Human Rights, it can be difficult to substantiate an individual allegation of ill-treatment when there is no official acknowledgement that it took place, in contrast to the allegations pertaining to the 'five techniques'. ${ }^{29}$ The way prisoners are treated is governed by many, sometimes competing, considerations, as we shall see in more detail in the following section of the paper.

A second interrogation operation in Aden that involved many more prisoners than the earlier negative operation took place between 1964 and 1967, against the National Liberation Front (NLF). In terms of reactions to allegations of torture and illtreatment from the British government and Amnesty International, this Adeni case bore some similarities to the later Northern Ireland case. Each prompted an investigation by Amnesty International and by an inquiry commissioned by the British government that contributed to a change in interrogation guidelines. When the disturbances began in 1964 the only intelligence assets at the Adeni government's disposal were the police force Special Branch and the interrogation centre at Fort Morbut. By Christmas 1965, however, Special Branch had all but ceased to exist because of the terrorist campaign against its members that included intimidation and assassinations. This made the work of the interrogation centre all the more important, and it was recognised as the main producer of intelligence in the period in question. ${ }^{30}$

\footnotetext{
${ }^{27}$ This list is based on TNA War Office (hereafter cited as TNA WO) 32/21726, 'Part II, Directive on interrogation by the armed forces in internal security operations: Instructions for individual operations', accompanying 'Directive on interrogation by the armed forces in internal security operations', (JIC(72)21), Joint Intelligence Committee (JIC), June 1972.

${ }^{28} \mathrm{HMSO}$, Report of the Inquiry into allegations against the security forces of physical brutality in Northern Ireland arising out of events on the 9th August, 1971, (Compton Report), 16 November 1971, Cmnd. 4825, paragraphs 69-77.

${ }^{29}$ King's Inns Library, Declan Costello's papers, Report of the European Commission of Human Rights, Ireland vs UK, adopted on 25 January 1976.

${ }^{30}$ TNA, Foreign and Commonwealth Office (hereafter cited as TNA FCO) 8/153, 'Note on the Security situation in Aden in December, 1965', High Commissioner (illegible), Government House, Aden, 25 January 1967; TNA DEFE 23/109, Bremner, 'Intelligence gained from interrogation operations', 18 November 1971.
} 
Its most notable successes, the MoD reported, were the discovery that Adeni government departments had been penetrated by Egyptian agents, and the identification of a political instructor and organiser of the NLF. ${ }^{31}$ When Denis Healey, who served as Labour prime minister Harold Wilson's Defence Secretary between 1964 and 1970, was briefed on the use of the 'five techniques' under Wilson's administration in preparation for his testimony to the Parker Committee, he was told that these techniques were not 'an interlocking set of procedures which were either used all together or not at all'. ${ }^{32}$ In the second Aden case, for example, no noise machine was used, simply because the continuous noise of the air-conditioning system fulfilled the same purpose. ${ }^{33}$

The final interrogation operation using the 'five techniques' before August 1971 was aimed at Maoist insurgents and took place between May and June 1970, again in December 1970 and one last time in January and February 1971. The location was withheld from the Parker Inquiry committee and this case was referred to only as 'operations'. The following quote on 'operations' demonstrates that in the view of the Intelligence Centre, the home of the Intelligence Corps and JSIW, this case represented the culmination of the previous eighteen years of work on the "five techniques' as aids to interrogation:

It was essentially this careful mounting of interrogation operations which enabled complete security to be planned and obtained, for the first time during the second phase of operations in the winter of 1970/71, and subsequently, when a requirement for interrogation was recognised in Northern Ireland. In all cases, small numbers of suspects were especially selected and were successfully interrogated in depth, in complete security and isolation. Hoods, wall-standing and noise...were used on each occasion to ensure complete isolation and consequent security, and to impose a degree of discipline which helped to create a proper working environment. ${ }^{34}$

To clarify, the term 'interrogation in depth' was sometimes used during the debates on the 'five techniques' that followed their use in Northern Ireland to mean interrogation for intelligence without use of these techniques, but in the quote above, as well as in the majority of other instances, it refers to interrogation using the "five techniques'. ${ }^{35}$ The quote makes clear the pride felt by the staff of the Intelligence Centre towards the techniques they had perfected during 'operations'. We shall return to the importance of security at the interrogation centre and how isolation encourages subjects to cooperate with their interrogators in the following section of the paper. We must be highly critical, however, of the integrity of these claims about the success of the 'five techniques' as aids to interrogation; yet this insight into the MoD's attitudes towards these techniques contributes to our understanding of the decision to transfer the 'five techniques' to Northern Ireland.

\section{THE VIEW FROM THE MINISTRY OF DEFENCE}

In the autumn of 1971 Sir James Dunnett hosted two meetings with other highranking members of the MoD, the Intelligence co-ordinator and the secretary of the

${ }^{31}$ TNA DEFE 23/109, 'Background note', unsigned [MoD], undated [November 1971?].

32TNA DEFE 23/109, 'Meeting with Mr Healey', Whitmore, 24 November 1971.

${ }^{33}$ TNA DEFE 23/111, 'The evolution of handling techniques in the interrogation environment', Headquarters Intelligence Centre, 8 December 1971.

${ }^{34}$ TNA DEFE 23/111, 'The evolution of handling techniques in the interrogation environment', 8 December 1971.

${ }^{35}$ See TNA DEFE 13/1118, George Cunningham, Member of Parliament for Islington South West, to Edward Heath, Prime Minister, 7 March 1972. 
Joint Intelligence Committee (JIC) to discuss interrogation and the 'five techniques'. Despite the backlash against revelations that the 'five techniques' had been used in Northern Ireland, these meetings were held to decide how to present the techniques to the Parker Inquiry in a way that would encourage the inquiry to recommend that the techniques continue to be available to British forces. The minutes of these meetings and documents on the same topic attributed to Intelligence Co-ordinator Sir Dick White provide insights into these officials' views regarding the 'five techniques'. They also detail how each of these techniques encourages subjects to cooperate with their interrogators, thereby expanding our understanding of the relationship between intelligence and what may be described as ill-treatment.

Those who attended the meeting held in the MoD on 23 November-who included Dunnett as chair, the vice-chief of general staff, the director-general of intelligence (DGI), the intelligence co-ordinator and the secretary of the JICaddressed the question of 'how far the five techniques... were in fact essential parts of the interrogation process' ${ }^{36}$ After considerable discussion it was agreed 'that the deprivation of sleep during the interrogation process itself, and the hard rations were all part of the interrogation process as such'. ${ }^{37}$ Sadly, no explanation for this assertion is provided. Perhaps what was meant is that deprivation of sleep can result from the many hours it can take for interrogation to succeed and the possibility that new intelligence can lead to re-interrogation. Significantly, such an interpretation does not acknowledge that sleep deprivation and offering 'plain food and water every six hours' 38 weakens resistance and encourages cooperation.

As we shall see, each of the techniques contributes to interrogation in a number of ways, directly and indirectly; but more is known about the contribution made by the most controversial of the techniques: hooding, wall-standing and white noise. The minutes from this meeting continued:

It was suggested that the other techniques viz hooding, wall standing, and noise, were essentially security measures although they did undoubtedly have the advantages that their use brought the prisoner under control and increased his sense of isolation. ${ }^{39}$

This dual purpose feature of the techniques later proved instrumental in the MoD's decision on how to present them to the Parker Inquiry. To understand this decision we must first examine the discussion of the effects of the 'five techniques' that informed it.

Hooding, wall-standing and white noise can be used in ways that grant security to prisoners, guards and the location of the interrogation centre. It is possible to describe the form these techniques took at Ballykelly, although there is little consensus between official claims and detainees' testimonies on how the techniques were applied or on the length of time for which they were used. Wearing a hood, officially a black pillow slip, was compulsory during transportation to the interrogation centre to protect its location, and while standing at the wall and being moved around the

${ }^{36}$ TNA WO 32/21776, 'Note of a meeting held by PUS on 23 November 1971 to discuss a draft historical paper on interrogation techniques for the Parker Committee', unsigned, 23 November 1971. Principle attendees were: Dunnett; Sir Dick White, intelligence co-ordinator; vice-chief of general staff; Air Marshal Harold Maguire, director general of intelligence (DGI); Arthur Hockaday, AUS(GS); Brigadier J. Lewis, Brigadier general staff (Intelligence) Defence intelligence staff (BGS(Int)DIS); and secretary JIC.

${ }^{37}$ TNA WO 32/21776, 'Note of a meeting held by PUS on 23 November 1971 to discuss a draft historical paper', 25 November 1971.

38TNA DEFE 23/108, Maguire to Private Secretary, Minister of State, 22 October 1971. This was required by standing order.

${ }^{39}$ TNA WO 32/21776, 'Note of a meeting held by PUS on 23 November 1971 to discuss a draft historical paper', 25 November 1971. 
centre to protect 'the identities of those selected for [this kind of] interrogation' ${ }^{40}$ Attendees at an earlier meeting called by Dunnett in October claimed that this was the main reason behind the use of hoods, with one claiming that "most of the detainees wanted to keep their hoods on in the cells quite voluntarily' to further protect them from identification. ${ }^{41}$ The Compton Inquiry was unable to reconcile evidence collected on the type of wall-standing applied in Ballykelly. Detainees told the inquiry that their hands were placed high on the wall and that they were forced with batons to maintain the posture, being lifted up again after collapse. In contrast, supervising staff claimed that although wall-standing was used for up to six hours, no excessive force was used to keep detainees in the posture; no batons were used for this purpose; and legs were not sufficiently wide apart, arms not sufficiently high and weight of the body not forward enough to render it a stress position. ${ }^{42}$

The Compton report gives the figures for the total time each of the fourteen men interrogated using the 'five techniques' in Northern Ireland spent standing at the wall as between 9 and 43.5 hours. ${ }^{43}$ These figures are inconsistent with those available in the archives, and although figures for hours spent in the interrogation room are available, some of the prisoners' time at the special interrogation centre remains unaccounted for.

Wall-standing achieves security for guards working at the centre by ensuring 'that hands are visible... and thus incapable of offensive action' ${ }^{44}$ White noise, which has been likened to a train letting off steam and is produced by an electronic noise generator, ${ }^{45}$ was used to "prevent inter-communication between detainees and to prevent detainees overhearing the interrogation of their associates or any other activity in the centre'. ${ }^{46}$ It can also prevent detainees from hearing noises from outside the centre that might identify its location. ${ }^{47}$ Officials claimed that white noise was not played in the individual cells at the Ballykelly centre, ${ }^{48}$ but this, and the level at which it was audible in the cells, is another point of contention. Despite inconsistencies and gaps in the available evidence, an impression of how hooding, wall-standing and white noise were used and their effects upon security can still be gained.

Sir Dick White was appointed to the new post of Intelligence co-ordinator in 1968, a post to which he brought considerable experience from his previous positions as head of MI5 and of MI6. In his report on prisoner handling at interrogation centres in Northern Ireland, commissioned in October 1971, drafted by the secretary of the $\mathrm{JIC}$ and circulated to the MoD, White recommended there be immediate investigation into the possibilities of securing improvements in 'the facilities, layout and construction (e.g., sound proofing)' of the interrogation centre in order that the "need for "hooding", "wall-standing" and "white sound"...be considerably reduced' ${ }^{49}$ This

${ }^{40}$ TNA WO 32/21776, 'Prisoner handling in interrogation centres in Northern Ireland: Report by the Intelligence co-ordinator', White, drafted by secretary, JIC, 2 December 1971.

${ }^{41}$ TNA DEFE 23/108, 'Note of a meeting held by PUS to discuss interrogation procedures at 15.50 on 26 October 1971', 28 October 1971, speaker's name and job have been redacted.

${ }^{42} \mathrm{HMSO}$, Compton Report, November 1971, paragraphs 57, 61-5. The minutes of a meeting chaired by Dunnett agree that wall-standing was used for a maximum of six hours because prisoners had to be fed at six-hourly intervals. TNA DEFE 23/108, 28 October 1971.

${ }^{43} \mathrm{HMSO}$, Compton Report, November 1971, paragraph 64.

${ }^{44}$ TNA, Northern Ireland Office (hereafter cited as TNA CJ) 4/97, I.R. Campbell, director of management and support of Intelligence, to secretary, JIC, 18 October 1971.

${ }^{45}$ TNA DEFE 13/918, Lt-Col E.J. Larner to Lewis, 25 November 1971; TNA DEFE 13/918, Lewis to VCGS, 25 November 1971.

${ }^{46}$ TNA WO 32/21776, 'Prisoner handling in interrogation centres in Northern Ireland: Report by the Intelligence co-ordinator', White, drafted by secretary, JIC, 2 December 1971.

47TNA CJ 4/97, Campbell to secretary, JIC, 18 October 1971.

${ }^{48}$ TNA DEFE 23/108, 'Note of a meeting held by PUS to discuss interrogation procedures at 15.50 on 26 October 1971', 28 October 1971.

${ }^{49}$ TNA WO 32/21776, 'Prisoner handling in interrogation centres in Northern Ireland: Report by the Intelligence co-ordinator', White, drafted by secretary, JIC, 2 December 1971. 
wish to mitigate the possible reasons why these techniques would be used in future was echoed by attendees at Dunnett's November meeting, who agreed that the Parker Inquiry could be told such intensive use of these three techniques at Ballykelly resulted from the inadequacy of the facilities there for urgent interrogation of up to twelve people at once. ${ }^{50}$ Work on preparing the special interrogation centre at Ballykelly had begun in March 1971, however, raising separate questions about the adequacy of these preparations and the integrity of the backward-looking use of the argument about resources. The JIC secretary wrote that hooding, wall-standing and white noise should be permitted in future, but only for their defensive (security) attributes, which he wrote could be provided for in the longer term 'at considerable expense in manpower and money for specially constructed buildings' ${ }^{51} \mathrm{He}$ was not, however, the only figure involved in these government debates who believed that, ultimately, these techniques provide 'when urgency is paramount, an essential ingredient in the process' of interrogation.

Before coming to the decision on how to frame this softening up effect in submissions to the Parker Inquiry committee, it is worth pausing on how these techniques encourage detainees to communicate with their interrogators. Many assertions of the importance of isolation and strict discipline that result from the 'five techniques' for the success of intelligence-gathering by interrogation can be found in material from the autumn of 1971,52 but there is only one instance in which the link between these effects and successful interrogation is spelled out. White produced this description when communicating what he understood was meant by the "psychological attack' permitted by JIC(65)15, the guidelines governing interrogation for intelligence in Northern Ireland..$^{53}$ These guidelines stated that this approach was a prerequisite for successful interrogation. White's description is worth quoting at length:

it must be demonstrated to [the suspect] that his freedom is now entirely within our control. He must be brought to realise that he is now entirely alone, and above all, completely severed from connections with his former comrades who can neither help him further nor condemn nor exact reprisals upon him. It is for him and him alone to decide whether it is best for him to cooperate with his interrogators, who will on their side be wise to make clear the relaxations that will follow such cooperation. The conviction of having reached the end of the road is all the more complete when the suspect reaches it through his own introspection during periods of isolation in his cell and by reading the signs of his defeat in the impersonal and disciplined demeanour and conduct of those who control and question him. ${ }^{54}$

It is thus clear how the 'five techniques', especially hooding, wall-standing and white noise, contribute to the softening up of prisoners; but as the 'five techniques' form only part of a prisoner's experience at the interrogation centre, the role of other aspects of prisoner handling must not be forgotten.

The key to the MoD-led decision on how to describe the functions of the interrogation techniques to the Parker Inquiry was the dual-purpose nature of the

${ }^{50}$ TNA WO 32/21776, 'Note of a meeting held by PUS on 23 November 1971 to discuss a draft historical paper', 25 November 1971.

${ }^{51}$ TNA DEFE 23/108, 'Report on interrogation methods used in Northern Ireland', draft, secretary, JIC to White, undated.

${ }^{52}$ For example: TNA DEFE 23/108, 'Note of a meeting held by PUS to discuss interrogation procedures at 15.50 on 26 October 1971', 28 October 1971; TNA DEFE 23/109, Bremner, 'Interrogation in internal security situations', 18 November 1971.

${ }^{53}$ TNA PREM 15/485, 'Joint directive on military interrogation in internal security operations overseas’ (JIC(65)15), JIC, February 1965, as amended in February 1967.

${ }^{54}$ TNA DEFE 13/918, 'Privy Councillor's enquiry: Note by the Intelligence co-ordinator', drafted by secretary, JIC, undated [December 1971?], DEFE 13/918, TNA. 
three most controversial techniques; this meant that these techniques could be presented as security measures without the ministry having to deny that they can be beneficial to interrogation by softening up prisoners. It is worth noting that the desire to retain approval for the techniques may have influenced the formulation of the statements presented above on the benefits of the techniques to security, including the claim that some prisoners favoured them for this reason, and the claim that limited resources can make the techniques harder to avoid. Dunnett and his colleagues at the November 1971 meeting then had to decide whether they:

should go as far as to say that these essentially security techniques were also used to some extent with the aim of bringing prisoners under control and increasing their isolation; or rather took [sic] the line that they were used essentially for security reasons but as a by-product had this effect. ${ }^{55}$

A solution to this problem was provided by White, who took the view that hooding, wall-standing and white noise should not be presented to Parker as 'an essential part of the softening up process', because using these techniques for this primary purpose 'does lay us open to possible charges of physical assault'. He argued the techniques could best be defended by explaining the security and safety measures made necessary by 'the special circumstances of the Northern Ireland emergency' ${ }^{56}$

This examination of the debates engaged in by members of the MoD and the Intelligence co-ordinator while the Compton and Parker Inquiry committees were carrying out their investigations reveals the effects of the 'five techniques' upon security; how the facilities available for interrogation affect the requirement for these techniques to be utilised; and how their effects upon prisoners encourage them to communicate with their interrogators. It has emerged that these members of the British intelligence community supported the 'five techniques' because they were beneficial to interrogations aimed at intelligence-gathering. The substance of these benefits will become clearer in the final part of the paper, when we analyse the success of the interrogation of the fourteen men in Northern Ireland in terms of the intelligence it produced.

\section{INTELLIGENCE OBTAINED IN THE NORTHERN IRELAND CASE}

The MoD produced material that relates to the success of the 'five techniques' in producing intelligence in Northern Ireland. One document in particular amongst those released into the public domain contains details of intelligence of the kind normally kept classified. Whereas this material provides an assessment of the efficacy of the 'five techniques' as aids to interrogation aimed at eliciting intelligence, it must be remembered that its production was influenced by the desire to protect these methods and that it is the only available account of what intelligence was obtained. ${ }^{57}$ To temper the strong claims of success implied by this summary of intelligence collected from the fourteen men at the special interrogation centre, we will also address some of the other outcomes, intentional and unintentional, of the use of such controversial interrogation methods within the United Kingdom.

An examination of whether the interrogation operation was a motivation behind the introduction of internment is beyond the scope of this paper, yet it can be asserted that preparations for interrogation aided by the 'five techniques' began as early as

\footnotetext{
${ }^{55}$ TNA WO 32/21776, 'Note of a meeting held by PUS on 23 November 1971 to discuss a draft historical paper', 25 November 1971.

56TNA DEFE 13/918, 'Privy Councillor's Enquiry: Note by the Intelligence co-ordinator', drafted by secretary, JIC, undated [December 1971?].

${ }^{57}$ The question of what intelligence was obtained during the interrogation of the fourteen men was not raised in Ireland's case before the European Commission of Human Rights.
} 
March 1971. Following Intelligence Co-ordinator Sir Dick White's visit to Northern Ireland to examine the 'intelligence picture' there, ${ }^{58}$ 'discussions were held in Whitehall by the departments concerned to examine the general question of interrogation in the context of a possible internment operation' ${ }^{59}$

As a result of these discussions the Head of RUC Special Branch... asked for help and advice in the setting up of an interrogation centre in Northern Ireland and for special training in interrogation for a team of 10 RUC Special Branch Inspectors. ${ }^{60}$

The JSIW 'has always been the professional centre for the study and development of [interrogation] techniques in the UK' ${ }^{61}$ and it is responsible for training those members of the British armed forces most likely to be captured during combat to resist methods of interrogation they may experience at the hands of their captors. Thus, the JSIW was selected to give the advice requested by the head of RUC Special Branch, David Johnston, and duly trained his officers in the 'five techniques' at a seminar held in April 1971.

Persons arrested under internment were initially questioned by police-first to confirm whether the right person had been arrested, then to establish whether the subject was to be questioned with a view to preferring a charge, whether the subject was worth more detailed interrogation, or if he should be released. ${ }^{62}$ Obtaining evidence for criminal cases was given more importance than collecting intelligence, and the two practices were clearly separated by location and the rules that governed them. As soon as an admission of criminal behaviour was made, subjects became the responsibility of the Criminal Investigation Department and were moved to a police station where they were questioned in accordance with the Judges' Rules, which govern the behaviour of police towards suspects, and which were not, Johnston claimed, compatible with collecting intelligence. ${ }^{63}$ Interrogation for intelligence, known as secondary interrogation, was governed by a set of JIC guidelines dating from 1965, as amended in 1967 in light of the Bowen Report into procedures 'for the arrest, interrogation and detention of suspected terrorists in Aden', which was the response to allegations of ill-treatment at the al-Mansoura detention centre and the Fort Morbut interrogation centre. ${ }^{64}$ These guidelines were replaced with a more restrictive set in June 1972 in response to criticisms of interrogation procedures sparked by events in Northern Ireland. This separation of police questioning and secondary interrogation is somewhat artificial, however, and can impede the transfer of intelligence obtained during police questioning to the machinery designed to analyse intelligence and disseminate it to decision-makers.

Subjects were selected for exposure to the 'five techniques' at Ballykelly by the RUC Special Branch on the grounds that they were 'known (or strongly suspected)

${ }^{58}$ TNA, Cabinet Office (hereafter cited as TNA CAB) 185/6, 'Intelligence arrangements: Northern Ireland', annex to minutes of JIC(A)(71) meeting, 25 March 1971.

${ }^{59}$ TNA DEFE 23/109, 'Background note', unsigned [MoD], undated [November 1971?].

${ }^{60}$ TNA DEFE 23/109, 'Background note'.

${ }^{61}$ TNA DEFE 23/117, Whitmore, 'The role of the army in interrogation in depth in Northern Ireland', 9 November 1971. After 1945 interrogation skills were the responsibility of Territorial Army unit IS 9, until the Interrogation Branch was formed at the Intelligence Centre (then in Maresfield) in 1956. In 1958 the branch was absorbed into the Interrogation School, before it became independent and was renamed the JSIW in 1965. TNA DEFE 23/109, Bremner, 'Interrogation in international security situations since $1945^{\prime}, 18$ November 1971.

${ }^{62}$ TNA FCO $87 / 158$, 'Interrogation by the security forces in Northern Ireland', to accompany JIC(72)21, undated, unsigned.

${ }^{63}$ TNA CJ 4/1744, Note of a meeting between David Johnston, head of RUC Special Branch, and Lord Windlesham on 2 May 1972.

${ }^{64}$ TNA PREM 15/485, JIC(65)15, February 1965, and amendment, 10 February 1967; HMSO, Report by Mr. Roderic Bowen, Q.C., on procedures for the arrest, interrogation and detention of suspected terrorists in Aden (Bowen Report), Cmnd. 3165, 14 November 1966. 
of being officers or officials of the IRA', ${ }^{65}$ and were 'thought to possess considerable knowledge of the IRA but... were considered unlikely to respond to normal police questioning'. ${ }^{66}$ Of the 342 men arrested in the initial internment sweep, 12 were deemed to have met these criteria and were subjected to the interrogation techniques for a period of 5-6 days in August 1971. Once it became apparent that the Compton Inquiry would cover events at Ballykelly, Special Branch became reluctant to conduct any further interrogation in depth. ${ }^{67}$ Philip Woodfield of the Home Office visited the chief constable of the RUC and head of Special Branch to make clear that approved interrogation methods did not fall within Compton's remit, and 'on this basis the RUC Special Branch withdrew their objection to further interrogation in depth' ${ }^{68}$ In October a further two men, the only other suspects considered suitable for this type of interrogation, were also put through the special interrogation centre, bringing the total number of people detained at Ballykelly to fourteen. ${ }^{69}$

Of these fourteen, however, official sources admit that two of the men were badly selected and produced no intelligence. No comments were made about why the first, Patrick McClean, ${ }^{70}$ was selected for interrogation using the 'five techniques'. Complaints made by the second of these men, Patrick Shivers, led a representative of the MoD office known as DS10, which had been established in November 1971 to deal exclusively with Northern Ireland, to state that Shivers was selected because records showed he was 'deeply involved in the higher echelons of the IRA and was politically implicated'. ${ }^{71}$ It was considered unlikely that he would confess such involvement in standard interrogation, and that detailed interrogation might help clarify his activities. ${ }^{72}$ The DGI, Air-Marshal Harold Maguire, judged that the intelligence dividends 'from 12 of the 14 confirm the basis for selection' ${ }^{73}$

A stimulating, though unqualified, summary of intelligence obtained from the fourteen men appeared in condensed form in the Parker Inquiry's report. In what is exceptional detail for a document released into the public domain, the intelligence obtained from the twelve men interrogated in August 1971 is described by the Parker report as:

(1) details of possible IRA operations, arms caches, safe houses, communications, supply routes for arms and explosives, and the location of wanted persons;

(2) over 40 sheets of IRA Order of Battle and details of approximately 500 IRA personalities; and

(3) over 40 outstanding major incidents were also cleared from Police records. ${ }^{74}$

65TNA DEFE 23/108, Maguire, 22 October 1971.

${ }^{66}$ TNA DEFE 23/119, 'Interrogation in Northern Ireland: an assessment of local factors affecting its operation, and a record of its value in security force activities', unsigned [MoD], November 1971.

${ }^{67}$ TNA DEFE 23/108, 'Northern Ireland-Interrogation in depth', unsigned and undated, covering letter by Hockaday, 13 October 1971.

${ }^{68}$ TNA DEFE 23/108, 'Northern Ireland-Interrogation in depth', covering letter by Hockaday, 13 October 1971.

${ }^{69}$ TNA DEFE 23/108, 'Northern Ireland-Interrogation in depth', covering letter by Hockaday, 13 October 1971.

${ }^{70} \mathrm{All}$ fourteen men were assigned numbers used in these documents. McClean, number 1 , was released on 14 August, Shivers, number 2, was released on 15 August. The other ten men were released earlier, on 13 August.

${ }^{71}$ TNA DEFE 23/117, C.H. Henn, DS10, MoD, 8 November 1971.

72TNA DEFE 23/117, Henn, 8 November 1971.

${ }^{73}$ TNA DEFE 23/108, Maguire, 22 October 1971.

${ }^{74}$ TNA DEFE 13/958, 'Intelligence gained from interrogations in Northern Ireland', unsigned [MoD], November 1971. This document will be published in Samantha Newbery, Bob Brecher, Philippe Sands and Brian Stewart, 'Interrogation, intelligence and the issue of human rights', Intelligence and national security (forthcoming, 2009). 
Information of a similar nature was collected from the two detainees who were interrogated in October; specifically, that information provided the:

(1) identification of over 180 members of both wings of the IRA and their position in the Order of Battle;

(2) allocation and descriptions of approximately 80 weapons;

(3) details of morale, operational directives, propaganda techniques, relationships with other organisations and future plans; and

(4) clearance of a further 45 major incidents outstanding on Police records. ${ }^{75}$

As part of efforts to justify publicly the controversial interrogation methods, statements made by Home Secretary Reginald Maudling and Prime Minister Edward Heath supported the argument that useful intelligence was gained by interrogation in depth and by broader secondary interrogation.

Responding to new allegations of ill-treatment published by the Sunday Times Insight Team on 17 October, Maudling stated that intelligence is of enormous importance in defeating the gunman', but nonetheless gave reassurance that these allegations would be investigated by the Compton Inquiry. ${ }^{76} \mathrm{~A}$ statement drafted for use by Heath on publication of the Compton report in November referred to the success of the 'five techniques' in obtaining 'a great deal of information about weapons and explosives and those who intended to use them for the murder of soldiers and policemen and the bombing of public places with loss of human life'. He added that 'as a result these activities have been severely curtailed'. ${ }^{77}$ The importance of intelligence for operations against terrorists and of collecting such intelligence 'while it is still fresh' was, at the Cabinet's request, enunciated in the Compton report. ${ }^{78}$ These claims, supported by the descriptions of the intelligence gained from the fourteen men interrogated at Ballykelly, are some of the most commonly given justifications for the use of these and similarly controversial interrogation methods.

The document summarising intelligence gained from the fourteen men at Ballykelly leaves significant questions unanswered. It does not comment on whether all this intelligence was new to the authorities; another source reveals that the order of battle information confirmed much of what was already known, that some gaps were filled and that the existence of IRA units previously unknown to authorities was revealed. ${ }^{79}$ Another weakness of that summary document, also attributable to its author's agenda, is that it does not comment on whether this intelligence might have been obtainable through any other, less intrusive or controversial, method. Stepping over these issues helped the MoD construct its case for the indispensability of the 'five techniques' as aids to gathering intelligence by interrogation in internal security operations.

Former secretary of the JIC Michael Herman wrote that intelligence activities and intelligence knowledge, including how that knowledge is used, 'can be examined separately but then have to be integrated into an ethical balance sheet' ${ }^{80}$ The government and MoD's view of the 'five techniques' as an intelligence-gathering

${ }^{75}$ TNA DEFE 13/958, 'Intelligence gained from interrogations in Northern Ireland', unsigned [MoD], November 1971.

${ }^{76}$ Commons Hansard, vol. 823, 19 October 1971, col. 547.

${ }^{77}$ TNA DEFE 23/108, draft statement by the prime minister, undated [15 or 16 November 1971?].

${ }^{78} \mathrm{HMSO}$, Compton Report, November 1971, paragraph 46.

${ }^{79}$ TNA DEFE 23/119, 'Interrogation in Northern Ireland: an assessment of local factors affecting its operation, and a record of its value in security force activities', unsigned [MoD], November 1971.

${ }^{80}$ Michael Herman, 'Modern intelligence services: have they a place in ethical foreign policies?', in Harold Shukman (ed.), Agents for change: intelligence services in the 21st century (St Ives, 2000), 289328: 290. 
activity, as is the focus of this paper, can be difficult to reconcile with the protection of the civil or human rights of prisoners, a tension that can be found at the centre of popular debates on what types of interrogation techniques can be justified. On how intelligence knowledge produced by the interrogation operation at Ballykelly was used, we have seen how the public statements attempting to justify these techniques referred to the lives saved by interrogation. Further assessment of how intelligence gained from the 'five techniques' was used first raises the question of exactly what intelligence, if any, was gained. Though there are examples of successful operations purported to have been facilitated by the interrogation operation as a whole, ${ }^{81}$ a wider assessment of the impact of intelligence gained from the fourteen men at Ballykelly upon the security situation in Northern Ireland is likely to continue to be frustratingly incomplete.

Intelligence-gathering activity can also be assessed on the basis of its wider effects, which in this case were far-reaching. Beyond the reluctance of the RUC to use the 'five techniques' after August 1971, however, it is difficult to separate results produced using the 'five techniques' from the ill-treatment sometimes experienced during other interrogations and at other stages of detention. David Charters has argued that once the details of the 'five techniques' became public knowledge and IRA propaganda inflated the claims about the interrogation techniques, 'for a while soldiers found it almost impossible to prevent arrested IRA members from telling all before they were handed to the appropriate authorities'; 82 nevertheless, there were long lasting detrimental effects as the legacy of the use of the 'five techniques' contributed to changes in the security situation in Northern Ireland.

\section{THE PARKER INQUIRY REPORT AND THE FUTURE OF THE 'FIVE TECHNIQUES'}

It is clear that key members of the MoD and British intelligence community in general retained their belief in the utility of the 'five techniques', despite the varied adverse effects they produced from August 1971. They were careful to present the techniques' intelligence and security benefits to the Parker Inquiry committee in a way that reflected their desire to retain them as tools for future interrogation aimed at the collection of intelligence. They expected the committee to adopt a similar position.

The members of the Parker Inquiry committee, however, were unable to reach a consensus on what changes should be made to Britain's interrogation guidelines, and as a result submitted a majority and a minority report to Cabinet ministers in February 1972. In their majority report Lord Parker and Mr Boyd-Carpenter recommended the 'five techniques' continue so long as safeguards against excessive use were instituted. Lord Gardiner's minority report found that the techniques were unlawful and not morally justifiable. ${ }^{83}$

On 2 March 1972 the Parker report was published; but at that time the Republic of Ireland was still gathering evidence of alleged breaches of the ECHR. A message from Edward Heath was passed to Taoiseach Jack Lynch on that day via the British

\footnotetext{
${ }^{81}$ For example, a Fianna N'a Eirann unit of 37 was disrupted when 25 of their number were arrested in Andersonstown, and the names of 15 members of Saor Eire were discovered when six of their members were arrested and questioned [these are the spellings given for these organisations in the original document]. At Ballymena on 13 November 1971 an arms cache was found that included 28 shotguns, 19 rifles, 1 anti-tank rifle, 9,840 rounds of ammunition, 1,500 feet of cordtex (detonator cord) and 45 pounds of gelignite, see TNA DEFE 23/119, untitled annex to 'Interrogation in Northern Ireland: an assessment of local factors affecting its operation, and a record of its value in security force activities', unsigned [MoD], November 1971.

${ }^{82}$ David A. Charters, 'Intelligence and psychological warfare operations in Northern Ireland', Journal of the Royal United Services Institute 122 (3) (1977), 22-7: 24.

${ }^{83} \mathrm{HMSO}$, Parker Report, March 1972. Lord Gardiner later chaired the committee behind the 1975 report into dealing with terrorism in Northern Ireland in the context of civil liberties and human rights.
} 
ambassador in Dublin. It forewarned the taoiseach of the imminent publication of the Parker report, provided him with a summary of the majority and minority findings, including a reference to past uses of the 'five techniques' 'under successive governments in various parts of the world', and informed him that the 'five techniques' would 'not be used in future as an aid to interrogation' ${ }^{84}$ Echoing other publicly made justifications for the authorised interrogation techniques used at Ballykelly, Lynch was reminded that the majority ruling noted that the 'five techniques' helped obtain information from the fourteen men that directly and indirectly led to innocent lives being saved, and that 'the lives saved were Irish' ${ }^{85}$

Heath's government decided 'in the British way...to err on the side of caution and not...permit the [five] techniques to be used in future as an aid to interrogation' by, or on behalf, of British forces. ${ }^{86}$ This decision recognised the pressure brought to bear upon the government by the reaction to the use of the 'five techniques' in Northern Ireland and went against the MoD's views. The ban was announced in the House of Commons alongside the publication of the Parker report and was encapsulated in new guidelines for interrogation in internal security operations as approved by the JIC in June 1972, replacing the 1965/67 guidelines. ${ }^{87}$ The decision to issue new interrogation guidelines, decisions on their form and the pressure caused by the case before the European Commission of Human Rights were between them some of the most tangible effects that the decision to use the 'five techniques' in Northern Ireland had upon the British government.

\section{CONCLUSION}

This study provides an insight into an example of intelligence-driven decision-making that took place within the context of an internal security operation. Although the documents produced by the MoD for the Parker Inquiry were composed with the clear intention of demonstrating with empirical evidence the strength of the intelligence benefits of using the 'five techniques' for interrogation, a picture emerges of how the pressures for tackling internal security problems and the importance of intelligence for tackling these kinds of problems can affect decision-makers. This study also reveals how strongly official efforts made after the fact to justify using the 'five techniques' in Northern Ireland relied upon the need to obtain intelligence.

The historical narratives of the 'five techniques' in particular go some way towards explaining how such techniques came to be a part of policy in Northern Ireland. Further light is shed on this decision, which many would judge as having been poorly made, by the attitudes displayed by the MoD towards the wisdom of the decision and towards the future usefulness of the techniques. This examination of the debates engaged in by senior members of the MoD and the Intelligence co-ordinator about how to respond to the Parker Inquiry's investigations has revealed the sheer strength of their continued support for the 'five techniques', and thus that the negative reactions to their use in Northern Ireland had little impact on their views. In addition to its contribution to understanding these views, the insight generated by this research into how the 'five' techniques' may be able to help interrogators collect valuable intelligence from their subjects also contributes to current debates on the relationship between intelligence and controversial interrogation techniques, which, in the words of a former intelligence professional, need 'more light and less heat' ${ }^{88}$

${ }^{84}$ TNA FCO 87/157, Heath to Jack Lynch, taoiseach; in Alec Douglas-Home, foreign secretary, to Dublin, 1 March 1972.

85TNA FCO 87/157, Heath to Jack Lynch, 1 March 1972.

86TNA FCO 87/157, Douglas-Home to missions and posts, 2 March 1972.

87TNA CAB 164/1329, JIC(72)21, 29 June 1972.

${ }^{88}$ Private correspondence to the author. 
Material collected by the Baha Mousa Public Inquiry on 'the Government, MoD and Army reaction to the use of the five techniques following the introduction of internment (including the...Parker report...) ${ }^{\prime} 89$ may further research in this area. Early indications are, however, that the inquiry is unlikely to hear any oral witnesses on the Northern Ireland case, and that the vast majority of documents it will examine from the early 1970s are already in the public domain. The senior counsel to the inquiry has also said publicly that the documents that are not already in the public domain are 'unlikely significantly to alter the picture of the historical assessment of the Government reaction to the use of the five techniques in the early 1970s'.90 Nevertheless, the material this inquiry makes available will facilitate future research into the important question of how controversial interrogation methods gain authorisation.

${ }^{89}$ Baha Mousa Public Inquiry, 'Provisional issues list', 19 November 2008; available at: www.bahamousainquiry.org. The inquiry is due to open formally on 13 July 2009.

${ }^{90}$ Baha Mousa Public Inquiry, 'Transcript of third directions hearing', 8 June 2009; available at: www.bahamousainquiry.org. 
